The University of Maine

DigitalCommons@UMaine

Publications

Senator George J. Mitchell Center for Sustainability

Solutions

$1-2015$

\title{
Understanding and Informing Permitting Decisions for Tidal Energy Development Using an Adaptive Management Framework
}

Teresa R. Johnson

University of Maine - Main, teresa.johnson@maine.edu

Jessica Spelke Jansujwicz

University of Maine, jessica.jansujwicz@maine.edu

Follow this and additional works at: https://digitalcommons.library.umaine.edu/

mitchellcenter_pubs

Part of the Natural Resources Management and Policy Commons, Oil, Gas, and Energy

Commons, and the Sustainability Commons

\section{Repository Citation}

Johnson, Teresa R. and Jansujwicz, Jessica Spelke, "Understanding and Informing Permitting Decisions for Tidal Energy Development Using an Adaptive Management Framework" (2015). Publications. 61.

https://digitalcommons.library.umaine.edu/mitchellcenter_pubs/61

This Article is brought to you for free and open access by DigitalCommons@UMaine. It has been accepted for inclusion in Publications by an authorized administrator of DigitalCommons@UMaine. For more information, please contact um.library.technical.services@maine.edu. 


\section{Understanding and Informing Permitting Decisions for Tidal Energy Development Using an Adaptive Management Framework}

Jessica S. Jansujwicz \& Teresa R. Johnson

J. S. Jansujwicz, Sustainability Solutions Initiative, University of Maine, 5710 Norman Smith Hall, Orono, ME 04469, USA

e-mail: jessica.jansujwicz@maine.edu

T. R. Johnson, School for Marine Sciences, University of Maine, 200 Libby Hall, Orono, ME 04469, USA

Keywords: Tidal power, Marine hydrokinetic technology, Adaptive management, Regulatory, Uncertainty, Permitting decisions, Renewable ocean energy 
Marine hydrokinetic (MHK) energy offers a promising new source of renewable ocean energy.

However, the young industry is faced with significant challenges. Most notable is the challenge of regulatory uncertainty that is thought to hamper the successful deployment of new tidal energy technologies. Adaptive management may be one approach to deal with uncertainty and inform permitting decisions for hydrokinetic projects. In this study, we apply the concept of adaptive management to the Cobscook Bay Tidal Energy Project in Maine to better understand and inform permitting decisions. Using a social science approach of observation, interviews, and document analysis, we examine (1) agency roles and authority, (2) agency interactions, (3) regulatory change, and (4) challenges faced in the regulatory and permitting process for MHK development at the federal and state level. We found four institutional factors favorable to an adaptive approach. These include experimentation and learning, institutionalized choice to correct avoidable error, a strong commitment to interagency coordination, and an emphasis on early proactive engagement with project developers. We also identified institutional challenges or vulnerabilities. These include conflicting agency cultures, high financial costs, and long timeframes associated with baseline data collection. Lessons learned from this study can assist regulators, policymakers, and project developers design and implement an actively adaptive management approach that can move new renewable ocean energy development forward in a way that is socially acceptable and environmentally responsible. 


\section{INTRODUCTION}

Growing concern over the threat of global climate change coupled with increasing population and rising energy prices has accelerated the search for practical alternatives to fossil fuels (Campbell 2009/2010; Pelc and Fujita 2002). In the search for new renewable energy sources, attention has increasingly turned toward the sea and the promise of ocean renewable energy. The oceans offer a vast and powerful source of renewable energy (Pelc and Fujita 2002), and energy from marine wind, tides, currents, waves, and ocean thermal gradients may all hold immense potential for electrical energy generation (Boehlert and Gill 2010). However, while the long-term prospects for ocean energy to supply a significant source of carbon-neutral energy appear promising (Griset 2010; Leary and Esteban 2009), the developing industry is faced with significant challenges. Most notable is the challenge of regulatory uncertainty that is thought to hamper the successful deployment of new ocean energy technologies.

Regulatory uncertainty has been identified as the most significant nontechnical obstacle for widespread commercialization of ocean energy (Anderson et al. 2007; Leary and Esteban 2009) and the primary barrier to the development of new wave and tidal energy technologies in the US (Bedard et al. 2007). Regulatory uncertainty is often attributed to the lack of clear jurisdictional authority and to the dearth of information on the potential impacts of new ocean energy technologies. An array of federal and state agencies assert jurisdiction over ocean renewable power projects, and developers must obtain a variety of permits from numerous regulatory agencies. The Federal Energy Regulatory Commission (FERC) is the lead permitting authority for hydroelectric projects, including new wave and tidal energy technologies. However, projects are also subject to permitting by the US Army Corps of Engineers (CORPS). At the state level, mandatory conditioning 
authority exists in the form of coastal zone management consistency determinations, granting of leases, and easements of state owned aquatic lands, certifications under Sect. 401 of the Clean Water Act, and additional authorities under the National Historic Preservation Act (16 USC 470 et seq.), Federal Powers Act (16 USC §§ 792), Fish and Wildlife Coordination Act (16 USC §§ 661-677e), and others (Anderson et al. 2007; FERC 2012). Additionally, federal and state agencies have the opportunity to comment on proposed projects pursuant to the Endangered Species Act (ESA; 7 USC $\S 136,16$ USC § 1531 et seq.), Marine Mammal Protection Act (16 USC § 1536a), and Magnuson Stevens Fisheries Conservation and Management Act (16 USC 1801 et seq.). As a result, project developers often find themselves faced with a confusing array of agency permitting requirements and considerable uncertainty exists around which regulatory processes and standards apply to their proposal. Developers charge that this regulatory complexity results in increased costs and a decreased ability to secure project financing (Griset 2010; Wellinghoff et al. 2008).

Further complicating the regulatory landscape for renewable ocean energy is the current lack of information on the potential impacts of new technologies. This is particularly evident with emerging innovative technology designed to capture energy from the natural movement of the tides, generally referred to as marine hydrokinetic (MHK) energy. Although very small and localized as compared to wind (e.g., Jacobson and Archer 2012; Marvel et al. 2013), tidal current energy is very predictable (Goundar and Ahmed 2013), and considerable potential energy exists for generating power from tidal currents off the coast of the US and elsewhere in the world using emerging technologies (EPRI 2005). However, because MHK technology is new, there have been few opportunities to evaluate their environmental impacts. Only a few devices have been deployed and tested in rivers and oceans, and even fewer environmental studies of these technologies have been 
completed (Cada et al. 2007, 2012). While studies are forthcoming (e.g., Viehman et al. 2012a; $2012 b$ this issue), there is currently little scientific data on the nature and scale of environmental impacts of MHK technologies with which to inform policy and permitting decisions.

In combination, jurisdictional issues and knowledge constraints beg the question: Within the context of uncertainty, how can a regulatory framework balance the need for an efficient process with the need for the responsible development of new renewable ocean energy technologies? One approach to this dilemma would be to design adaptive management policies, in which there is a deliberate attempt to find some optimal balance between resource protection and the "disruptive probing" or scientific analysis necessary (Walters 1986) to gain a better understanding of both the long-term impacts and long-term potential of wave and tidal energy devices. The concept of adaptive management is not new, nor is its application to tidal energy development. Oram and Marriott (2010), for example, embraced the concept of adaptive management as a means for proceeding with agency permitting of wave and tidal energy projects in the face of uncertainty. They suggest that an adaptive management approach would allow projects to be permitted and installed, while simultaneously providing agencies and other stakeholders with the opportunity to collect data on potential environmental impacts. Following an adaptive management approach, changes to the regulatory structure could then be made in response to new information and problems that may emerge during the installation process.

As an approach, adaptive management has been supported in government policies to encourage research and development in ocean renewable energy at the federal and state level (e.g., Ocean Energy Task Force OETF 2009). More recently, the emerging tidal power industry has also begun to apply principles of adaptive management to project planning and implementation 
(e.g., FERC 2012). However, although increasingly supported by the industry and government (e.g., Bornholdt 2012; Konnert 2010), few if any case studies have empirically examined the validity of using an adaptive management approach to move tidal energy development forward in a more efficient and responsible manner. In this research, we suggest that opportunities and challenges for developing commercial-scale tidal power projects is best understood through the conceptual framework of adaptive management. To this end, we apply the concept of adaptive management to a study of MHK development in Maine, USA to better understand and inform permitting decisions for this new generation of tidal energy devices. Our study focuses on the Portland, Maine-based Ocean Renewable Power Company's (ORPC's) Cobscook Bay Tidal Energy Project. Adaptive management is a key component of ORPC's approach (FERC 2012), thus the Cobscook Bay project provides an excellent opportunity to learn from early experience with adaptive management and inform future applications of the concept to tidal energy development in Maine and beyond.

Within the context of the Cobscook Bay project, we pursued three main objectives. First, we aimed to understand and describe the regulatory and permitting process for MHK development in Maine. This included an analysis of the various federal and state agencies involved, their jurisdictional authority, roles, and decision making process. Our second objective was to examine the agency and developer perspectives on the process of tidal energy development, including their perspectives on regulatory change, knowledge gaps, and challenges faced in the project licensing process. Our final objective was to inform future regulatory and permitting decisions for tidal power projects in Maine and beyond. To accomplish this, we draw on the Cobscook Bay project to explore the concept of adaptive management. Our purpose was to highlight lessons learned from 
the first hydrokinetic pilot project licensed within the US to inform the practical application of adaptive management in the context of renewable energy development.

\section{CONCEPTUAL FRAMEWORK FOR ADAPTIVE MANAGEMENT}

Adaptive management is conceptualized as a way to confront uncertainty in natural resource issues (Gunderson 1999; Holling 1978; Walters 1986). It recognizes that managed resources will always change as a result of human intervention, that surprises are inevitable, and that new uncertainties will emerge (Gunderson 1999). As a concept, adaptive management embraces policies as experiments with the goal of learning from them so that future decisions can proceed from a better base of understanding (Lee 1993). This approach involves a continual learning process based on the assumption that you cannot know that something will work until you try it (Walters 1986). In other words, adaptive management is a deliberate and explicit commitment to "learn" from experience (Halbert 1993) or to the process of "learning by doing" (Walters and Holling 1990).

As an experimental approach, adaptive management recognizes that policies must be continually modified and flexible so that they can adapt to surprise and new information as learning occurs (Gunderson 1999). Indeed, an essential characteristic of adaptive management is that a direct feedback loop exists between science and management (Halbert 1993). In theory, feedback from inventory, monitoring, and evaluation is used to improve decision making by allowing for management and policy decisions to be modified in light of new scientific information (Halbert 1993). However, while adaptive management considers change and adaptation as inherent to management, Johnson (1999) observed that "most management institutions tend to resist change 
and wish to control the process of management as much as possible." This may explain why adaptive management has been more significant as a concept than a management practice (Lee 1993).

Turning to the literature, we suggest ways to move the concept of adaptive management from theory to practice. In considering future applications of adaptive management, Johnson (1999), for example, highlights the need to develop new institutional arrangements, so that adaptive management experiments are applied not just to the resource but also to the institutions themselves. According to Johnson (1999), "these experiments would explore the relationships within and among agencies and stakeholders to find new ways to promote flexibility, cooperative management, and long-term outlook." Lee (1993) also focuses on institutional factors that could demonstrate the viability of adopting adaptive management as a strategy for sustainable development. He suggests that there are factors that favor adaptive management but also institutional conditions or "vulnerabilities" that may limit institutional learning and responsiveness to the approach. Among the favorable institutional factors posited by Lee (1993) are the following: a mandate to take action in the face of certainty, awareness of experimentation by decision makers, commitment to improve outcomes over biological time scales, sufficient resources, availability of theory, models, and field methods for evaluation, testable hypotheses, institutional patience, and an organizational culture that encourages learning from experience. Institutional vulnerabilities include the disruptive capability of policy changes, vulnerability to political change, agency operating staff concerns, and "the requirement that the adaptive manager be an able negotiator as much as a visionary scientist" (Lee 1993, 80). This conceptual understanding of adaptive management is particularly applicable to our study of MHK development in Maine. In 
particular, our study offers an excellent opportunity to examine the institutional arrangements that may support or hinder the success of adaptive management as a flexible approach for dealing with uncertainties in tidal energy development.

\section{STUDY CONTEXT}

Our research takes place within the context of ORPC's Cobscook Bay Tidal Energy Project. Since 2005, ORPC has been working with the federal and state agencies to secure the necessary approvals to construct and operate a tidal energy project in Cobscook Bay, off the coast of Eastport and Lubec in Washington County, Maine. Cobscook Bay lies at the entrance to the Bay of Fundy, where the mean tidal range is about $6 \mathrm{~m}$ (Brooks 2004). In 2005, the Electric Power Research Institute (EPRI) identified this site as one of the best sites for tidal energy development in the US (EPRI 2005).

ORPC's Cobscook Bay Tidal Energy Project proposes to use the tidal currents of Cobscook Bay to generate electricity via a cross-flow kinetic system turbine generator unit mounted on the seafloor. This TidGen ${ }^{\mathrm{TM}}$ power system will capture energy from the ebb and flow of the water beneath the surface. In 2007, ORPC obtained an initial preliminary permit from FERC. This preliminary permit did not authorize construction but served to maintain ORPC's priority for the site and allowed the company to study the feasibility of the site and prepare license application materials. In 2011, ORPC completed a 1-year test of a beta pre-commercial version of their TidGen ${ }^{\text {TM }}$ power system. About a year later, in March 2012, FERC granted ORPC an 8-year pilot license to construct, maintain, and operate a 330-kW tidal power project in Cobscook Bay (FERC 2012). Developed by FERC in 2008, a pilot license process allows developers to test new hydroki- 
netic technologies, to determine appropriate sites for these technologies, and to confirm the technologies' environmental effects without compromising FERC's oversight (FERC 2008). Pilot project licenses must be small, short term, avoid sensitive locations, subject to modification or shut down if unforeseen impacts occur, subject to plans for monitoring and safeguarding public safety and environmental resources, and removed with the site restored at the end of the license term, unless a commercial license is issued (FERC 2008). Under the FERC pilot project license, ORPC was required to develop an adaptive management plan (FERC 2012). Upon obtaining the FERC pilot license, the Cobscook Bay Tidal Energy Project became the first hydrokinetic tidal energy project within the US to gain approval to connect to the interstate power grid. Construction of the first phase of the Cobscook Bay Tidal Project began in March 2012.

\section{METHODS}

The research presented here is part of a larger ongoing study of tidal energy development in Maine. In this paper, we draw on social science research conducted between April 2010 and June 2012 aimed at understanding and documenting the regulatory and permitting process for tidal energy development. This research consisted primarily of semi-structured and informal interviews, discussions with key agency, industry, and other stakeholders, direct observations of the policy process, and a review of relevant documents.

To better understand the regulatory and permitting process for tidal energy development, we conducted 16 semi-structured interviews to learn directly from the participants involved. Interview participants were selected purposively through document analysis, network sampling, and our observations. Participants included 12 federal and state agency representatives, 1 private 
consultant, and 3 industry developers. Agencies included the FERC, the US Fish and Wildlife Service (USFWS), the National Marine Fisheries Services (NMFS), US Coast Guard (USCG), CORPS, Maine Department of Environmental Protection (DEP), and the Maine Department of Marine Resources. Interview questions were open-ended and designed to identify major themes related to the regulatory process and tidal energy development, particularly focused on the Cobscook Bay Tidal Energy Project. During the 1-2-h interviews, we asked the participants about their role in the process, their interactions with the agency and industry stakeholders, and their perceptions of the regulatory and permitting process as it has unfolded over time, including any knowledge gaps or challenges faced. Interviews were audio recorded and transcribed. Additionally, we had numerous informal interviews and discussions with agency regulators and project developers throughout the research. These interactions were recorded in extensive field notes.

We also attended meetings related to our research topic. These included two US Coast Guard public meetings on the proposed navigation regulation for the Cobscook Bay Tidal Energy Project, two informal consultation meetings between ORPC and federal and state regulatory and resource agencies, and one offshore renewable energy industry technical meeting. Public meetings and agency consultations were audio recorded and transcribed. Detailed field notes were recorded at all meetings attended. Lastly, we reviewed key documents including government publications (e.g., agency guidance, FERC license applications, and biannual project progress reports), media articles from national, regional, and local papers, and audio from local broadcasts related to tidal energy development in Cobscook Bay. Meetings, documents, and media sources provided additional insights into how the process of tidal energy development proceeded at the federal, state, and local level. They also provided insight into the various roles that different stakeholders 
played in the process. Using multiple sources of data also enhanced the credibility of our results and confirmed our emerging findings (Merriam 2009).

Semi-structured interview transcripts, public meeting transcripts, and field notes from meetings and informal interviews and discussion were entered into a QSR-NVivo 9 database for storage and qualitative analysis. For qualitative analysis, we used a modified grounded theory approach (Glaser and Strauss 1967; Strauss and Corbin 1990) that focused on identifying emerging themes, patterns, and relationships in the ways that participants described their experiences with the regulatory and permitting process for MHK development. The results and discussion presented below are focused on these themes including (1) agency role and authority, (2) coordination, (3) regulatory change, and (4) challenges faced in the regulatory process for tidal energy development at the federal and state level in Maine.

RESULTS

Agency Role and Authority

The regulatory and permitting process for tidal energy development mandates involvement by an array of federal and state agencies. We draw on data from interviews supplemented by document review and our field notes to identify the role, authority, and timing of agency involvement at the federal (Table 1) and state (Table 2) level in Maine.

Interview participants highlighted major laws that structure the decision making process and place power and authority with lead federal and state agencies. Participants viewed the process of MHK development as "primarily driven by the federal agencies" with FERC assuming the 
lead role. FERC has authority to issue a final licensing decision; however, an array of federal and state agencies (cooperating agencies) have "mandatory conditioning authority" within the FERC process for a particular aspect of tidal energy development under a particular statute (see Tables 1 and 2). In general, the agencies with mandatory conditioning authority were perceived to wield more power in the decision making process (e.g., FERC under the Federal Powers Act; US Army Corps of Engineers under the Rivers and Harbors Act) as opposed to those provided with commenting opportunities (e.g., US Fish and Wildlife Service under the Fish and Wildlife Coordination Act). In the case of the Cobscook Bay Tidal Energy Project, permits from FERC and CORPS are "critical to whether something gets off the ground or not," thus these agencies are thought have more influence in the decision making process. However, the laws themselves also shaped the process by determining which agencies play a larger role in decision making. For example, as described by a federal regulator, resource agencies "only get to have that kind of power if we get to a jeopardy call or an adverse modification of critical habitat (under the ESA) otherwise its more recommendations." This indicates that authority (and thus agencies involved and the laws applied) may shift depending upon the issue on the table. A federal official gave examples. He said:

Army Corps leads the way when it comes placing structures in the water. FERC leads the way when it comes to generating electricity, and the Coast Guard leads the way when it comes to obstructing the navigational waterway.

Responsibility may also shift depending on the project and unique characteristics of the site. These factors determine the regulatory pathway in which decisions are made. For example, a federal regulator discussed how, in their agency, the "strength of decision making in the whole pro- 
cess really depends on what type of consultation we are doing." If it is an informal consultation (few species and no adverse effect), NMFS's decision is "probably not the biggest decision being made in the process." If there are only minor ESA concerns, NMFS may "fade into the background." On the other hand, in a formal consultation (finding of adverse effect), NMFS issues a biological opinion with terms and conditions on "take." A federal regulator sums up their influence:

Depending on the severity of the effect, we can either have a very major role, stop or potentially stop a project, or a very minor role in essentially just saying, we'd like it if you could use BMP's for sedimentation and erosion and work when the fish aren't there.

At the state level, similar trends emerge. Agencies with mandatory conditioning authority (DEP) assume a larger role in the process. According to a state regulator, "There are three decision makers, FERC, Army Corps, and DEP. The other agencies, all the other resource agencies just submit comments." The Department of Conservation (DOC) and the Maine State Planning Office (SPO), however, submit more than comments. DOC issues a submerged lands lease and SPO makes a decision regarding concurrence or objection to a consistency determination under the Coastal Zone Management Act (Table 2). Not surprisingly, at both the state and federal level, agencies involved with the marine environment play a larger role than agencies with a focus on terrestrial or freshwater habitats. Accordingly, NMFS, USCG, and USFWS were identified as having a "big place at the table," while "Maine Inland Fisheries and Wildlife probably would not commit a lot of resources to the project process."

Coordination - Coordination was a dominant theme that emerged in discussions of agency 
involvement in the regulatory and permitting process. Interview participants spoke of coordination within agencies, interagency coordination, and coordination between agencies and project applicants. Within agency coordination was particularly salient for NMFS. Because NMFS has two divisions, the Habitat Conservation Division that implements the ESA and the Protected Resources Division that takes the lead role on the Federal Powers Act and the Magnuson Stevens Conservation Act, heavy coordination between the two divisions is necessary. Similarly, a FERC regulator spoke of the coordination that is required between the three divisions in his agency-licensing, administration, and compliance, and dam safety. He said, "going through the licensing proceeding, we work hand in hand with Compliance to ensure that when we issue a license, that the requirements in it make sense to them."

Interagency coordination and early proactive engagement with developers were also dominant themes. A federal regulator said:

There's a general recognition that federal agencies should work together and if there's a way to facilitate or streamline for energy related projects, we should do it. Doesn't mean we will permit everything that comes through the door, it just means if we can get through the end of a review process in an expedited manner, while meeting our regulations and responsibilities, we should.

FERC and CORPS were identified as two agencies that played a key role in coordinating the regulatory and licensing process for MHK development. A federal regulator said:

At the federal level, FERC and the CORPS...all try to bring our various federal partners to the table as early as possible to work cooperatively throughout our various 
processes to avoid duplication of effort.

Interagency coordination was highlighted by FERC as a critical step to ensure that all agencies understood their role in FERC's licensing process:

We're working as much as we can behind the scenes to try to coordinate with the other federal agencies so that they understand better how they fit in because the goal of our licensing process is to make sure all other agencies have their own statutory needs met under our process as kind of a one stop shop.

Coordination between federal and state agencies was also important. A state regulator explained:

If there's an environmental issue out there that needs to be addressed, not only for DEP but probably for the CORPS too, we coordinate those, so you don't have two meetings on whether or not the noise from driving pilings is going to be a problem for salmon. You have one meeting on that.

By avoiding a duplication of effort, it was thought that agencies could focus their time and the applicant's time as wisely as possible. FERC and DEP tried to work together to coordinate environmental impact analysis meetings in terms of a pre-application document and the types of studies that should be done to assess impacts on fish, seabirds, whales, dolphins, and other concerns. One federal regulator emphasized the need for frequent pre-and post-meeting follow-up to make sure agencies, developers, and other stakeholders are all "on the same page." Similarly, another federal regulator said:

We interact primarily with the other resource agencies in developing a uniform or 
similar set of resource issues ... so that one agency doesn't tell them [the developer] one thing, our agency tells them something different. We try to make sure we have a common understanding of the resource issues and present one view to a licensee.

Agency regulators described positive interactions with ORPC and commented on the developer's proactive engagement. One federal regulator said, “...At ORPC, a lot of their principals and project managers...they've all been very good at engaging us early and often."

Regulatory Change

Federal Regulatory Change - Participants discussed three modifications or adaptations in the regulatory and permitting process at the federal level. One of the changes was the Verdant exclusion. In 2005, FERC issued a declaratory order for a developer, Verdant Power, who was looking to install six hydrokinetic turbines in the East River, New York, without having to get a license from FERC. The Commission found that they could do so "provided that they met the criteria that they would be small, short-term, and that they are not to be connected to or displace power from the interstate power grid." In describing this permitting option, a FERC regulator said: "The purpose of that was really to try to reduce some of the regulatory barriers." The second key regulatory change emerging from discussions with regulators and developers was the evolution of the pilot licensing process. Consistently, study participants discussed how the regulatory process in place for MHK projects, prior to the pilot license process, was designed for conventional hydroelectric projects (dams) and did not meet the needs of developers looking to test the economic feasibility of new tidal energy technology. A federal regulator pointed out, "prior to, (the pilot license process), there was no process. The technology was ahead of policy." Instead, project 
developers had to go through existing licensing processes to obtain necessary approvals from FERC. A federal regulator with experience in conventional and MHK technology said many developers "felt that those processes were a bit more time consuming, kind of cumbersome, and expensive for these newer technology projects that were quite different than conventional." As a result, FERC was charged with streamlining the regulatory process and reducing barriers to MHK development. The pilot license process that emerged was designed specific to tidal power to test and monitor new technology. As described by a FERC regulator:

The pilot license is unique to MHK, and that came about, basically...even though we have this Verdant Exclusion available for people to get in the water quickly, theoretically, a lot of the developers, the industry in general, felt like they still need to be able to connect to the grid to really fully test their projects. So the Commission kind of listened. We had a work-shop...basically to get information from the industry and stakeholders, trying to find out what the Commission could do to try to reduce barriers and the pilot license is something that kind of came out of that.

As perceived by a project developer, the FERC pilot process was developed to stimulate a domestic renewable ocean energy industry by offering a "permitting path targeted to emerging companies with new technologies." This process allowed developers to get into the water to test their new devices. Federal regulators also acknowledged the nascent technology and emerging process:

This is a relatively novel process aimed at streamlining some of the hurdles that they [project developers] would've ordinarily gone through, because FERC understood that not all these projects could be developed. The preliminary process was really 
largely designed to give folks, potential developers an opportunity to look at a certain site, at a certain technology, to see if it was economical.

The third change in the regulatory and permitting process was the Strict Scrutiny Policy. This policy emerged in response to concern that "a lot of developers were going and locking up sites with these (preliminary) permits and not really making any progress toward developing a license application." There is a low bar to get preliminary permits because they do not authorize any activity. There are no National Environmental Policy Act requirements because there is no ground disturbing, construction, or operation. FERC initially received a large number of permits, but only a very small number of permit holders actually moved into licensing. As described by a FERC regulator, the Strict Scrutiny Policy came about in response to this "flurry of activity in hydrokinetics" as a way to "bring down the numbers" by "making sure that the people who are getting the permits are serious about trying to move forward." Under the Strict Scrutiny Policy, the applicant is required to file a schedule of activities of what they plan to do under the permit, semiannual progress reports, and then if they are going to be seeking a long-term commercial license or a short-term pilot license, they have to file "kick-off" documents within the first 2 years of the permit. As the FERC regulator said:

Really the thing is with the Strict Scrutiny Policy is we said that we would cancel permits where we're not actually seeing progress being made, and we have had to do that on a number of occasions.

State Regulatory Change - At the state level, a Memorandum of Understanding (MOU) between FERC and the State of Maine (2009) institutionalized changes to the federal and state review process for tidal project permit applications. The purpose of the MOU was to "coordinate 
the procedures and schedules for review of tidal energy projects using hydrokinetic technologies" to ensure that coordinated review is "responsive to environmental, economic, and cultural concerns while providing a timely, stable, and predictable means for developers of such projects to seek necessary regulatory and other approvals" (FERC and State of Maine 2009). Participants in our study identified the MOU as a key change that added predictability to the process of tidal energy development. For example, they spoke of the commitment by the state to act "much quicker" on Sect. 401 water quality certifications. A state regulator described this process:

We figured out that a little bit of a snag we have is in part of our general rules that deal with processing of all applications. There's a time frame of fifteen working days from when we receive an application to when we have to make a determination whether or not that application is complete. When it comes to the tidal power project, we got caught in an infinite duel up here for a little while. FERC was telling ORPC, you have to submit your state application at the same time you submit your pilot license application with FERC. [DEP] can't deem their general permit application at the state level complete until FERC issues a Finding of No Significant Impact (FONSI)...FERC doesn't issue a FONSI within fifteen days of the initial, application process.

Ultimately, what emerged from efforts to coordinate at the federal and state level was an agreement to suspend the permit application until FERC made a decision. According to a federal regulator, "even though the developer filed proof that they filed an application with the state, the state basically said they were going to hold it in abeyance until FERC issued a FONSI and then they would consider the application." 
Learning by doing: Regulatory changes noted above were discussed within the context of "learning by doing." This is exemplified by a quote from a FERC regulator who said:

As a Commission we're kind of learning as we're going along. We're going to try to do the best we can at adapting as we go. We're trying to be forward thinking, in terms of what potential unique issues we'll have with these types of projects, but we do expect things to continue to adapt. I've seen it just within the pilots, the first two that have come through, some minor modifications or adaptations that we had to make to unique issues.

A "learning by doing" approach was based on the assumption that because hydrokinetic devices are a new technology, regulators do not really know what the impacts are or what protective measures should be prescribed until the technology is deployed and monitored.

Participants in our study admitted that, at least initially, they knew very little about the regulatory process for MHK development. However, they felt they gained knowledge "in doing" that would be useful in future applications. One state regulator said that he faced a "pretty steep learning curve" in understanding the FERC process, but that he was learning "by making mistakes and doing it." He said, "I'm getting it. I'm starting to learn." When asked about his experience and satisfaction with the Cobscook Bay Tidal Energy Project, the regulator said, "Well, I've hoped I made the state part go smooth anyway, because this is the first one, and how often when you do something the first time, do you do it exactly right?" Similarly, a federal official said:

I can tell you that internally lessons learned, hindsight being $20 / 20$, we learned a bunch of things. Mistakes are not the right word here, but our approach would be 
somewhat different next time. We would take what we learned and be a whole lot more proficient in how we deal with this.

Another official in the same agency echoed this sentiment. He said, "You know, we're learning as we go along. I'm hopeful that we're going to learn enough from the Cobscook Bay project so the next one is going to be very much more streamlined."

Many spoke of the opportunity to inform the licensing process by learning "in the water." A federal regulator said:

The pilot process is experimental. It's designed to collect information both on the technical design of the technology but also to address environmental impacts. Our decisions have led to multiple monitoring plans, so in terms of the way this project has been going and hopefully data collection that will inform future projects, this has been very significant.

Similarly, in moving forward as the first in-water hydrokinetic project in the US, ORPC felt that they were "maturing a regulatory pathway." They viewed their work, in partnership with the University of Maine, as "blazing the trail" by setting standards for environmental monitoring.

Much like we're pioneering technology we're pioneering the permitting process. Because it's new, and while there is a process that exists, different elements of it are somewhere undefined, and we're defining it as we get to it.

Challenges

Four key challenges to the MHK permitting and regulatory process emerged from our 
analysis as follows: (1) knowledge gaps and uncertainties, (2) long timeframes and high financial costs of baseline data collection, (3) timing of agency involvement, and (4) conflicting agency cultures.

Knowledge Gaps - References to "limited information" and "uncertain" or "unknown" environmental impacts of new hydrokinetic technology consistently emerged from our interview transcripts and field notes from observations, meetings, and informal discussions. Our data also showed widespread agreement that, in contrast to conventional hydropower, there is limited environmental information to inform MHK permitting decisions. Similar to conventional hydropower project licensing, resource agencies must use the best available science to determine whether a tidal project will adversely affect a species. In the case of MHK development, however, regulators have limited scientific data with which to base their decision on. A federal regulator noted:

If we had the general sorts of studies like in a hydropower project...what sorts of impacts would accrue to resident fish that live in the reservoir, to migratory fish that move downstream as juveniles or must get upstream, past the dam-without ever having done a study of the project or a proposed project, we could say with some certainty, what the sorts of impacts were going to be. It's only a matter of finding the specifics of that site. We can't do that with hydrokinetic. We don't know the relative impact of those in a generic sense on the resources so our regulatory job is made much more difficult.

Our study identified information needs that agencies, developers, and other stakeholders thought should be addressed related to tidal energy development. Overwhelmingly, our data 
showed that impacts to marine resources were a significant concern and a major data gap. As a federal regulator pointed out, "at the very early stages of this, there wasn't a lot of information, there were thoughts that the interactions (of the turbine) with marine species, wouldn't necessarily lead to injury or death, but there wasn't a lot of data supporting that."

Direct and indirect impacts to fish topped the list of concerns. A federal regulator said, "The big question that always jumps out is: what are the interactions between the fish present and the technology being deployed?" Resource agencies wondered whether fish would avoid the turbines or be attracted to them. If fish swam through them, would they get disoriented, injured, or killed if struck by a turbine blade? State regulators also wondered whether turbines would affect fish migration, or serve as a magnet for predatory species. Aside from fish species such as herring and salmon, there was significant concern regarding impacts to other marine resources, specifically birds (e.g., diving ducks and eagles) and marine mammals.

Resource and regulatory agencies were also concerned about impacts to abiotic resources. For example, regulatory and resource agencies were concerned about whether the installation of the structures would affect water flow or tidal regimes. They were also concerned about physical disturbances to the environment such as impacts to the substrate. Other issues identified included the electromagnetic field effect around buried transmission cables and water quality concerns.

Agency personnel and project developers were concerned about the lack of site-specific information, ranging from area circulation models to data on local use of navigable waterways. They considered this information critical for characterizing the proposed tidal energy site. Speaking to this, an ORPC developer said: 
A lot of the site information in this area is not really readily available on any coastal atlas, any kind of data portal that might be available, so we've had to kind of create our own database.

To fill this data gap, ORPC is working with "all those people that have buoys in different areas, different eyes in the water" to obtain site-specific information. Another site-specific information gap we noted was information on local marine uses. Specifically, the USCG expressed a need to better understand traffic patterns, including information on types of vessels, frequency of transit, and types of activities those vessels were involved with. One official said, "I can tell you for Cobscook Bay that was difficult to find." The USCG has two automated systems to determine traffic. The first one is called AIS or automated identification system and a second system for commercial fishing boats is called VMS or vessel monitoring system. VMS, often referred to by fishermen as an "electronic ankle bracelet," manages the fisheries by knowing where the boats are and what they are doing. The USCG official explained:

VMS, it shows where they are and it shows how fast they're going and because you can't trawl very fast and you normally transmit faster than you trawl, you can kind of infer some activities just based on speed.

Although these two data systems are in place, they are not effective for documenting traffic patterns in remote areas such as Eastport, ME. With regards to the Cobscook Bay Tidal Energy Project, the USCG official said:

I got zero AIS hits and zero VMS hits in that area. So, there's no way to characterize the traffic and that's going to have a big impact on the stakeholders. If you wanted to describe all the stakeholders, those two tools can't be used. 
So instead of an electronic information system that systematically records marine traffic, USCG had to rely on anecdotal information from a local law enforcement officer to characterize the waterway based on the number of scallop draggers or lobstermen who fish Cobscook Bay during various seasons.

Long Timeframes and High Financial Costs - Hydrokinetic projects are complex and take considerable time. As one state regulator described, the long-timeframe for the Cobscook Bay Tidal Energy Project, he said: “They haven't even built anything yet. That's just five years pushing paper around and collecting some information." High cost associated with information needs of an experimental approach is also a significant challenge. Under their statutory authority, agencies require the collection of baseline information during the licensing process. As a regulator explained, "under the pilot licensing process, more study is required during the timeframe that the project is out there (in the water)." These studies, however, are capital intensive, and ORPC developers point out that there are few available funding sources to support that work. Moreover, from ORPC's perspective, "the baseline information that the agencies want has no direct relationship to the turbine in the water, and the impact of marine life with the turbine." Thus, they question whether they should be asked to conduct the same types of studies and baseline analysis required of more conventional dam project proposals. An ORPC developer thought the agencies should provide these data "so that developers don't necessarily have to spend as much time, money, and effort on collecting data to satisfy those agencies."

Timing of Involvement - As previously noted, agency representatives we interviewed commented that ORPC engaged them early and often. However, there was the perception by one 
federal agency that they were not brought into the process early enough. An official from one of the regional offices of this agency said:

We would look for a great deal more guidance, in terms of how we can collaborate together to determine exactly what the impact is and get to the bottom of things like the navigational safety plan. When they (ORPC) came to us and said "Hey, we are thinking about this," it was already full steam ahead. My point is that we need to be a bit more unified.

Learning from this experience, the official commented that in the future, "one of the things that we would do is get on board immediately, for example with the Army Corps of Engineers and make sure we are more connected with them and FERC." Rather than wait to learn about the project after it had already gained momentum, the agency would seek more proactive collaboration.

Conflicting Agency Cultures - We noted tensions between the new pilot licensing process and an agency's traditional standard operating procedures. An ORPC developer said: The pilot project process is geared to support, innovation. The resource agencies hate innovation. They want "knowns." And, you know, stable outcomes, and ongoing regular operations as opposed to something that's experimental. And if it's experimental, it needs to be a situation that has been thoroughly vetted and then published in the right literature...which could take years.

In working with the agencies to address risk and uncertainty, ORPC found that some agency personnel were more receptive to change than others. Some were "problem solvers" who 
understood that the technology and process of MHK development was different than conventional hydropower possibly requiring a different approach. Others were "problem identifiers" who attempted to force the new industry into the existing regulatory structure. As one (ORPC) developer said:

Some of the agency personnel, what they are doing runs counter a little bit to how their agency has done business. So, we've got to work with the agencies so that they don't feel at risk, that we are not asking them to do something that they feel they can't do.

From their perspective, moving the permit process forward was "a constant negotiation process" to find a balance between testing new technology while safeguarding the environment. ORPC stressed that they will continue to be open with their information, keep the agencies updated on a regular basis, and try to work with agency personnel "in a way that helps them maneuver through that gauntlet internally" and "help get this done the right way."

\section{DISCUSSION}

In our research on the Cobscook Bay Tidal Energy Project, we identified key components of an adaptive management approach. We also identified institutional challenges that may affect adaptive management. Here, we consider favorable and "vulnerable" institutional factors (Lee 1993) emerging from the Cobscook Bay case to demonstrate the viability of using adaptive management as a strategy for the responsible development of tidal power.

First, we found that decision makers in our study encouraged learning from experience. There was the perception among those interviewed that feedback from monitoring and evaluation 
could be used to improve decision making. Decision makers recognized that a number of studies were needed to fill knowledge gaps and uncertainties related to hydrokinetics, particularly turbine resource interactions. However, there was also widespread recognition that the only way to determine the feasibility and effects of hydrokinetic projects was to "learn by doing." In effect, this created a "chicken and egg problem." As described by Anderson et al. (2007), a "chicken and egg" situation occurs because regulators need to understand potential impacts before allowing technology to be deployed on a commercial scale, but some level of deployment is necessary to better understand those potential impacts. Because an adaptive approach favors action (Lee 1993), it may offer a way forward. In the Cobscook Bay case, favorable institutional arrangements allowed for in situ evaluation of pilot (demonstration) projects. The pilot process is an approach that enables experimentation and learning to take place so adjustments can then made to project design, operation, and licensing.

Second, an adaptive approach offers choices by instituting a plan to correct avoidable error (Lee 1993). Regulatory policies for hydrokinetic energy are structured to avoid unacceptable risk to the local marine environment. By limiting the scope of new MHK projects, the pilot process reduces the risk for regulatory agencies charged with protecting natural resources in the public interest. Instead, regulators have the choice to stop and remove a project with the site restored if the impacts prove too high. As Lee $(1993,64)$ notes, "This discretion is the key to the political feasibility of an adaptive policy." While pilot licensing guidelines provide a favorable institutional arrangement, however, laws such as the ESA could significantly impact the ability to implement an adaptive management strategy, especially in an experimental context. If an endangered species is placed in jeopardy, for example, there is a limit to the use of adaptive management. 
Third, our study showed that adaptive management experiments are applied not just to the resource (e.g., examination of fish turbine interactions and technological changes), but also to the institutions themselves (Johnson 1999). In our study, an institutional factor favorable to adaptive management was the strong commitment to coordinate federal and state permitting activities. From a decision making perspective, adaptive management crosses jurisdictional boundaries (Lee 1993), making interagency cooperation essential. Improved coordination between FERC and DEP was as an important institutional change that reduced redundancies and resolved timing issues that caused friction between state and federal processes. These changes resulted in a more expeditious and streamlined permit application review process that allowed hydrokinetic projects to get in the water faster, while still ensuring proper environmental safeguards. Additional changes will continue to occur as agencies push for earlier and more proactive engagement.

Fourth, early and proactive engagement with project developers offered a strategy to deal with risk and uncertainty. Given the high level of scientific uncertainty involved in MHK development and the sheer number of studies that could be required of an applicant, early and frequent meetings between applicants and agencies emerged as critically important. Ideally, proactive engagement could help identify what the information needs are, what information is already available, and allow various agencies to weigh in on the types of studies really necessary for a given project site. This approach is a constant negotiation process that requires patience, a key characteristic of adaptive management as identified by Lee (1993).

Lastly, our study highlighted "institutional vulnerabilities" (Lee 1993) that may hamper the application of an adaptive management approach, namely high financial costs associated with 
baseline studies and conflicting agency cultures. Collecting baseline biophysical data over multiple seasons is required to adequately characterize a proposed tidal energy site. However, knowledge accumulates slowly, and the process is cost intensive. At the same time, industry needs to continue to show progress to attract investors. Furthermore, constraining the hydrokinetic industry is conflicting agency cultures. Regulators want "knowns" (e.g., data on resource turbine interactions) before making decisions on permit applications. This may make innovative regulatory change difficult to accomplish within the framework of traditional agency decision making structures.

Tidal energy development is characterized by high scientific and economic uncertainty, and in this context, an adaptive approach makes sense. However, if institutional conditions do not support efficient learning from experience, adaptive management may fail to produce effective action. Drawing on the factors that favor and affect adaptive management, we recognize that there are still many questions that need to be answered before regulators can "feel really comfortable" with tidal power. However, information produced through experimentation and social learning can be used to guide management and inform the future development of new renewable ocean energy technology. Although we focus on a specific case of hydrokinetic energy development, lessons learned in the regulatory and permitting process for the Cobscook Bay Tidal Energy Project are widely applicable to ocean energy projects within Maine and beyond. Lessons learned from our study of tidal energy development in Maine can assist regulators, policymakers, and project developers design, and implement an actively adaptive management approach that can move new renewable ocean energy development forward in a way that is socially acceptable and environmentally responsible. 


\section{ACKNOWLEDGMENTS}

This research was supported by the National Science Foundation award EPS-0904155 to Maine EPSCoR Sustainability Solutions Initiative at the University of Maine. The authors would like to thank the biologists, regulators, and developers for generously sharing their time and perspectives on the process of tidal energy development. 


\section{FIGURES}

Table 1 Role, authority, and timing of involvement of federal agencies in MHK development

\begin{tabular}{|c|c|c|c|}
\hline Agency & Role & Timing of involvement & Applicable laws and policies \\
\hline $\begin{array}{l}\text { Federal Energy } \\
\text { Regulatory } \\
\text { Commission (FERC) }\end{array}$ & $\begin{array}{l}\text { - Authorizes construction and operation of all } \\
\text { non-federal power projects, including hydrokinetic } \\
\text { - Issues preliminary, pilot, and commercial licenses } \\
\text { - Grants exclusions for hydro projects not connected } \\
\text { to grid (Verdant Exclusion) }\end{array}$ & $\begin{array}{l}\text { Filing of Preliminary } \\
\text { Permit application } \\
\text { NEPA Analyses }\end{array}$ & $\begin{array}{l}\text { - Federal Power Act } \\
\text { - Public Utility Regulatory Policies Act } \\
\text { - Energy Policy Act } \\
\text { - Electric Consumers Protection Act } \\
\text { - National Environmental Policy Act }\end{array}$ \\
\hline $\begin{array}{l}\text { National Marine Fisheries } \\
\text { Service (NMFS) }\end{array}$ & $\begin{array}{l}\text { - Consultation (informal or formal) with action } \\
\text { agencies pursuant to Section } 7 \text { of ESA } \\
\text { - Issues Biological Opinion to action agency } \\
\text { for endangered species } \\
\text { - Section } 18 \text { Fishway Prescription under FPA }\end{array}$ & Pre-application & $\begin{array}{l}\text { - Magnuson Stevens Conservation Act } \\
\text { (Essential Fish Habitat, EFH) } \\
\text { - Endangered Species Act } \\
\text { - Fish and Wildlife Coordination Act } \\
\text { - Federal Power Act } \\
\text { - Marine Mammal Protection Act }\end{array}$ \\
\hline $\begin{array}{l}\text { U.S. Army Corps of } \\
\text { Engineers (CORPS) }\end{array}$ & $\begin{array}{l}\text { - Consultation with applicant and other agencies } \\
\text { - Issues permits for construction activity in } \\
\text { navigable waters, including temporary and } \\
\text { permanent installations }\end{array}$ & Pre-application & $\begin{array}{l}\text { - Section } 10 \text { of Rivers and Harbors Act } \\
\text { - Section } 404 \text { of the Clean Water Act } \\
\text { - Section } 103 \text { of the Marine Protection } \\
\text { and Sanctuaries Act }\end{array}$ \\
\hline U.S. Coast Guard (USCG) & $\begin{array}{l}\text { - Reviews and provides opinions on impacts to } \\
\text { navigation \& navigation safety } \\
\text { - Provides guidance and federal regulations that } \\
\text { may be required } \\
\text { - Issues permits for Private Aids to Navigation }\end{array}$ & $\begin{array}{l}\text { Application filed with } \\
\text { FERC and CORPS }\end{array}$ & $\begin{array}{l}\text { - Private Aids to Navigation Program } \\
\text { (PATON) }\end{array}$ \\
\hline $\begin{array}{l}\text { U.S. Fish and Wildlife } \\
\text { Service (USFWS) }\end{array}$ & $\begin{array}{l}\text { - Reviews and provides opinions on impacts to } \\
\text { natural resources, primarily birds. } \\
\text { - Issues Biological Opinion to FERC for } \\
\text { endangered species } \\
\text { - Section } 18 \text { Fishway Prescription }\end{array}$ & Pre-Application & $\begin{array}{l}\text { - Endangered Species Act } \\
\text { - Fish and Wildlife Coordination Act } \\
\text { - Federal Power Act } \\
\text { - Migratory Bird Treaty Act } \\
\text { - Bald \& Golden Eagle Protection Act }\end{array}$ \\
\hline
\end{tabular}




\begin{tabular}{|c|c|c|c|}
\hline Agency & Role & Timing of involvement & Applicable laws and policies \\
\hline $\begin{array}{l}\text { Department of } \\
\text { Environmental } \\
\text { Protection (DEP) }\end{array}$ & $\begin{array}{l}\text { - Issues water quality certification } \\
\text { - Coordinates state agency review and } \\
\text { permit under the Maine Waterway } \\
\text { Development \& Conservation Act }\end{array}$ & $\begin{array}{l}\text { - Development of preapplication } \\
\text { document }\end{array}$ & $\begin{array}{l}\text { - Clean Water Act Section } 401 \text { (d) } \\
\text { - Maine Waterway Development and } \\
\text { Conservation Act }\end{array}$ \\
\hline $\begin{array}{l}\text { Maine Department of } \\
\text { Marine Resources (DMR) }\end{array}$ & $\begin{array}{l}\text { - Reviews project application and } \\
\text { comments on proposed plan and } \\
\text { impacts to trust resources } \\
\text { - Participates in joint interagency } \\
\text { preapplication meeting with DEP }\end{array}$ & $\begin{array}{l}\text { - Application filed with FERC } \\
\text { - May be involved in consultation } \\
\text { in pre-filing } \\
\text { - Pre-application } \\
\text { - Integrates with DEP permit process }\end{array}$ & - Maine Endangered Species Act \\
\hline $\begin{array}{l}\text { Maine Department of Inland } \\
\text { Fisheries and Wildlife } \\
\text { (IF\&W) }\end{array}$ & $\begin{array}{l}\text { - Review project application and } \\
\text { comments on impacts of proposed } \\
\text { plan on trust resources }\end{array}$ & $\begin{array}{l}\text { - Application filed with FERC } \\
\text { - May be involved in consultation } \\
\text { in pre-filing } \\
\text { - Pre-application } \\
\text { - Integrates with DEP permit process }\end{array}$ & - Fish and Wildlife Coordination Act \\
\hline $\begin{array}{l}\text { Maine Department of } \\
\text { Conservation (DOC) }\end{array}$ & - Issues Submerged Lands Lease & $\begin{array}{l}\text { - Early in planning process } \\
\text { - Pre-application }\end{array}$ & - Submerged Lands Leasing Program \\
\hline $\begin{array}{l}\text { Maine State Planning } \\
\text { Office (SPO) }\end{array}$ & $\begin{array}{l}\text { - Consistency determination with } \\
\text { the Coastal Management Program }\end{array}$ & $\begin{array}{l}\text { - Early in planning process } \\
\text { - Integrates with DEP permit process }\end{array}$ & - Coastal Zone Management Act \\
\hline $\begin{array}{l}\text { Maine Historic Preservation } \\
\text { Commission }\end{array}$ & $\begin{array}{l}\text { - Determines whether and how a } \\
\text { proposed action may affect historic } \\
\text { properties } \\
\text { - Consults with FERC and Corps on } \\
\text { ways to avoid or minimize any } \\
\text { adverse affects }\end{array}$ & - Pre-filing & $\begin{array}{l}\text { - National Historic Preservation Act } \\
\text { (NHPA) }\end{array}$ \\
\hline
\end{tabular}




\section{REFERENCES}

Anderson, F., G. Achterman, S. Padula, and M. Harte. 2007. A programmatic approach to wave energy planning: Opportunities for the Oregon Wave Energy Trust. Proceedings of Coastal Zone 07 Portland Oregon (July 22-26, 2007).

Bedard, R., M. Previsic, G. Hagerman, B. Polagye, W. Musial, J. Klure, A. von Jouanne, U. Mathur, C. Collar, C. Hopper, and S. Amsden. 2007. North American ocean energy status-March 2007. Electric Power Research Institute (EPRI) Tidal Power (TP); Volume 8, 2007.

Boehlert, G.W., and A.B. Gill. 2010. Environmental and ecological effects of ocean renewable energy development: a current synthesis. Oceanography 23(2): 68-81.

Bornholdt, M. 2012. Ocean renewable energy from a national perspective. Danvers, MA: Energy Ocean Conference 2012. June 19-21, 2012.

Brooks, D.A. 2004. Modeling tidal circulation and exchange in Cobscook Bay, Maine. Northeastern Naturalist 11(2): 23-50.

Cada, G., J. Ahlgrimm, M. Bahleda, T. Bigford, S.D. Stavrakas, D. Hall, R. Moursund, and M. Sale. 2007. Potential impacts of hydrokinetic and wave energy conversion technologies on aquatic environments. Fisheries 32: 174-181.

Cada, G.F., A.E. Copping, and J. Roberts. 2012. Ocean/tidal/stream power: Identifying how marine and hydrokinetic devices affect aquatic environments. Hyrdoworld.com [Accessed June 10, 2012].

Campbell, H.V. 2009/2010. A rising tide: Wave energy in the United States and Scotland. Sea Grant Law and Policy Journal 2(2): 29-48.

EPRI. 2005. Ocean tidal and wave energy, renewable energy technical assessment guide-TAG-RE (2005). Palo Alto, CA: Electric Power Research Institute. 2005. 1010489.

FERC. 2008. Federal Energy Regulatory Commission Licensing Hydrokinetic Pilot Projects http://www.ferc.gov/industries/ hydropower/geninfo/licensing/hydrokinetics/pdf/white_paper.pdf (issued April 14, 2008.

FERC. 2012. Ocean Renewable Power Company: Order issuing pilot project license Minor Project), Cobscook Bay Tidal Energy Project Project No. 12711-005 (February 27, 2012).

Glaser, B.G., and A.L. Strauss. 1967. The discovery of grounded theory: strategies for qualitative research. Chicago, IL: Aldine.

Goundar, J.N., and M.R. Ahmed. 2013. Design of a horizontal axis tidal current turbine. Applied Energy 111: 161-174.

Griset, T.J. 2010. Harnessing the ocean's power: opportunities in renewable ocean energy resources. Ocean and Coastal Law Journal 16(2): 151-190.

Gunderson, L. 1999. Resilience, flexibility, adaptive management - antidotes for spurious certitude? Conservation Ecology 3(1): 7. [online] URL: http://www.consecol.org/vol3/iis1/art7.

Halbert, C.L. 1993. How adaptive is adaptive management? Implementing adaptive management in Washington State and British Columbia. Reviews in Fisheries Science 1(3): 261-283.

Holling, C.S. 1978. Adaptive environmental assessment and management. London, UK: John Wiley.

Jacobson, M.Z., and C.L. Archer. 2012. Saturation wind power potential and its implications for wind energy. Proceedings of the National Academy of Sciences 109(39): 15679-15684.

Johnson, B.L. 1999. Introduction to the special feature: Adaptive management - scientifically sound, socially challenged? Conservation Ecology 3(1): 10. [online] URL: http://www.conecol.org/vol3/ iis1/art10/.

Konnert, T. 2010. The role of the Federal Energy Regulatory Commission in authorizing hydrokinetic technology projects. Oceanography 23(2): 54-59.

Leary, D., and M. Esteban. 2009. Climate change and renewable energy from the ocean and tides: calming the sea of regulatory uncertainty. The International Journal of Marine and Coastal Law 24: 617-651.

Lee, K.N. 1993. Compass and gyroscope: integrating science and politics for the environment. Washington, D.C.: Island Press. 
Marvel, K., B. Kravitz, and K. Caldeira. 2013. Geophysical limits to global wind power. Nature Climate Change 3: $118-121$.

Merriam, S.B. 2009. Qualitative research: a guide to design and implementation. San Francisco, CA: Wiley. Ocean Energy Task Force (OETF). 2009. Final report of the Ocean Energy Task Force to Governor John E. Baldacci. Augusta, Maine. www.maine.gov/spo/specialprojects/OETF/Documents/ finalreport_123109.pdf [Accessed May 24, 2012].

Oram, C., and C. Marriott. 2010. Using adaptive management to resolve uncertainties for wave and tidal energy projects. Oceanography 23(2): 92-97.

Pelc, R., and R.M. Fujita. 2002. Renewable energy from the ocean. Marine Policy 26: 471-479.

Strauss, A.C., and J.M. Corbin. 1990. Basics of qualitative research: grounded theory procedures and techniques. Thousand Oaks, CA: Sage Publications.

United States Federal Regulatory Commission and State of Maine. 2009 Memorandum of Understanding (August 2009), http:// www.ferc.gov/legal/maj-ord-reg/mou/mou-ma.pdf.

Viehman, H., G.B. Zydlewski. 2012b. Fish interactions with a commercial-scale tidal energy device in the natural environment. Estuaries and Coasts. (THIS ISSUE).

Viehman, H., G.B. Zydlewski, J.D. McCleave, G. Staines. 2012a. Using acoustics to understand fish presence and vertical distribution in a tidally dynamic region targeted for energy extraction. Estuaries and Coasts. (THIS ISSUE).

Walters, C.J. 1986. Adaptive management of renewable resources. New York, NY: McGraw-Hill.

Walters, C.J., and C.S. Holling. 1990. Large-scale management experiments and learning by doing. Ecology 71(6): 2060- 2068.

Wellinghoff, J., J. Pederson, and D.L. Morenoff. 2008. Facilitating hydrokinetic energy development through regulatory innovation. Energy Law Journal 29: 397-42. 